\title{
Relevance of Communication Strategies and Funding Orphanages in Ghana
}

\author{
Wilberforce S. Dzisah \\ Ghana Institute of Management and Public Administration (GIMPA) School \\ of Liberal Arts and Social Sciences (SOLASS), Greenhill-Achimota \\ E-mail Address: wdzisah@yahoo.com;wdzisah@gimpa.edu.gh \\ DOI//http://dx.doi.org/10.4314/gjds.v16i3.5
}

\begin{abstract}
This paper examined the relevance of communications strategies in improving domestic funding of orphanages in Ghana and in particular SOS Children Villages. With funding difficulties being faced by both State and non-State actors such United Nations Children's Fund, most of the orphanages are struggling to generate enough funds to take care of the social needs of the orphanages. The study used quantitative (constructivist) and qualitative (motivations, ideas and opinions) methods to address the key objectives of the paper - funding deficiencies and the critical role of the media and communication strategies in solving the problem. It established the importance of communication strategies using media dependency and advocacy theories for social mobilization and behavioural change. The paper concludes that orphanages need a communication strategic plan for advocacy and resource mobilisation. A key recommendation is for a national policy framework to assist establish an endowment fund for orphanages. Such a national policy should make it mandatory for the Ghanaian media to offer their platforms for advocacy and fundraising activities by the orphanages.
\end{abstract}

Keywords: Communication, Funding, Media, Orphanages, SOS CV Ghana

\section{INTRODUCTION}

The plight of orphans and vulnerable children has been recognised across the world when Hermann Gmeiner in 1949 laid the foundation stone for the first SOS Children's Village in Imst, Austria. This was in reaction to the shock and horror at the plight of so many children left orphaned and homeless after the Second World War. In the case of Ghana, deteriorating socio-economic life, urbanization, excruciating poverty caused by social inequalities began to produce orphans, street children and other vulnerable groups in the society. The response to the menace was the establishment of the first SOS Children's Village in the industrial city of 
Tema in 1974. This was followed by others in Asiakwa, Kumasi, and Tamale. While these are supposed to be Non-Governmental Organizations (NGOs) in Ghana, the Department of Social Welfare (DSW) was established and mandated as the regulatory body to work directly with SOS Children's Villages and other orphanages. Orphans and Vulnerable Children (OVC) are classified as those below age of eighteen (18) who have lost one or both parents, and who are exposed to moral, physical and psychological danger as a result of neglect and/or abuse or incapacity whether a parent is alive or not (Department of Social Welfare, 2012).

\section{Poverty and Domestic Funding}

The problem of orphans, street children and other vulnerable groups is being exacerbated by urbanization and industrialization. Due to inexplicable factors such as deaths, re-marriage of widowed or divorce women, absence of love and security, unwanted pregnancy of sexually exploited girls, these orphans and street children are left without care and support. The end result is that these children are then drawn into rag picking, pick pocketing and other anti-social criminal activities. Several studies and researches carried out on children have maintained that children have a right to be cared for and grow up with their biological parents so as to live in a family environment (O’Donoghe, 2014).

Although most governments and international laws have recognised the fact that children have a right to grow up with their biological parents, experience have shown that millions of children are living in residential institutions around the world even though with no clear statistical figures (Berens \& Nelson, 2015). Today, SOS Children's Villages International is active in 134 countries and territories around the world, helping hundreds of thousands of children each year through familybased alternative care, schools, health centres, family strengthening programmes, and other community-based work. The United Nations-accepted framework for the alternative care of children was developed with input from SOS Children's Villages and other child-focused Non-Governmental Organizations (NGOs).

A new report from Save the Children reveals that in many countries four out of five children in 'orphanages' still have a living parent. The proportion is even higher in some countries. In Central and Eastern Europe almost every child in an institution - 98\% - has at least one living parent. In Indonesia that figure is at $94 \%$ and in Ghana 90\%. Orphanages with very little supervision have become a moneymaking venture for some in Ghana (Mensah, 2010). The fact that $90 \%$ of children in institutions have one or more parents alive deepens the suspicion that the homes are set up more to cater for the economic needs of the caterers rather than the kids in need. Again in Ghana, the number of homes has increased from ten in 1996 to 
more than 140 in 2009 and 400 in 2015 (Department of Social Welfare, 2015). The Department of Social Welfare (DSW) also claims that from 2009 to 2012 in Ghana, the number of Residential Homes for Children (RHC) operating in the country had increased by 169 per cent from 55 in 2005 to 148 in 2012 and they catered for about 4,500 children.

This exponential increase placed millions of children at risk. The dangers of living in institutions, including rape, exploitation, trafficking, beatings, torture, and psychological harm must not be discounted. Children are also likely to experience the trauma of being separated from parents who, with the right support, could look after them at home (Nelton, 2015). Globally, eight million children are estimated as currently living in orphanages and other institutions but the actual number may be much higher because many are not registered. Poverty accounts for the main reason why children end up in institutions rather than the death of a parent. For poor families, putting their children in an institution can be the only way to cope, particularly when shocks like natural disasters, conflict, illness or family breakdown compound the problem of poverty (ibid).

This rise, however, has not been matched by increase in funding for the residential homes as revealed by a performance audit report of the Auditor-General conducted on four sampled regions (Greater Accra, Western, Northern, and Ashanti) and three other homes in the Central Region. According to the A-G's report on the regulation of residential homes for children (orphanages) by the DSW, the only fund available for use by the DSWs planned activities was the Government of Ghana (GoG) funds, which excluded salaries and allowances (Department of Social Welfare, 2015). The funds have been categorised into direct Government of Ghana (GoG) funding, Livelihood Empowerment against Poverty (LEAP), the United Nations Children's Fund (UNICEF) and Internally Generated Funds (IGFs). Nonetheless, the report indicates that while the amount of money received by the DSW increased by 43 per cent from 2008 to 2009, it dropped by 65 per cent from 2009 to 2010 .

Clearly, since the introduction of SOS Children's Villages Ghana (SOS CV Ghana) over four decades ago, their operations continue to be hampered by inadequate funding. The resource constraints of most of these institutions could be attributed to the ever decreasing government funding which are occasioned by dwindling revenue streams, political and institutional corruption, misapplication and misplaced priorities. The funding limitations have the tendency to hamper these institutions from taking in more of such orphans and other vulnerable persons within this social class. This paper therefore settled on a conceptual foundation with media dependency and advocacy theories as well as concepts explicating communication strategies providing a solid framework. The paper recognises that a key component 
dealing with the challenges is the adoption of effective communication strategies by SOS CV Ghana in a bid to shore up its funding gaps so as to continue to deliver socially beneficial services to these groups.

The main objective of the paper is to examine the relevance of communications strategies in improving domestic funding of orphanages in Ghana using SOS Children's Villages Ghana as a case. Specifically, the paper seeks to identify communication strategies that SOS Children's Villages Ghana adopts in ensuring effective fundraising system within the domestic environment; assess the factors that contribute to effective fundraising by SOS Children's Villages in Ghana and to identify the challenges that SOS Children's Villages Ghana encounter in raising funds locally. To address these objectives, the paper settled on a research design which deployed both qualitative and quantitative methods of data collection and analysis. A total sample of 30 respondents comprising of 20 staff and 10 managers across the four SOS CV Ghana homes were selected from a staff population 90 . The quantitative research approach is constructivist while the qualitative explored the underlying motivations, ideas and opinions responsible for a particular phenomenon (Moffat, 2015; Creswell, 2003). In using these designs, interviews and questionnaires were employed to obtain primary data from sampled staff and management of SOS Children's Villages Ghana.

\section{Conceptual Framework and Communication Strategies}

The efficiency of orphanages as Non-Governmental Organizations is linked to their ability to engage with donors and to receive money from them to fund and cater for the children. In essence, there is the need to source for domestic funding to help improve and positively impact the lives of the children. Education and health are among the most important factors which can turn the lives of these children around, particularly those who are orphaned or vulnerable.

Education, for example, gives children hope for life and work. It is essential that education is accessible to all. Ghana seems to have an overall good legal and policy framework guaranteeing the right to education. The country has ratified most key international treaties, and the right to free and compulsory basic education is guaranteed by the Constitution of Ghana as enshrined in Article 25 and supported by a number of policies. However, NGOs and international organizations have pointed out that an important gap remains between the right to education in law/ policy and the practical application of this right. Factors such as corruption, lack of motivation, and poor implementation might have contributed to this gap (Right to Education Factsheet Ghana, 2012). 
The calls for various communication strategies to identify a sponsor, corporate partners, institutional partners as well as philanthropists to improve domestic funding of SOS CV Ghana are aimed at tackling the myriad of needs and of these Homes. As has been revealed by some of the respondents, the SOS Villages have made some strides by incorporating communication strategies in their plans so as to improve on their domestic funding. It is, therefore imperative, in the light of this to test the efficacy and relevance of the communications strategies in use with the view to improve domestic funding of SOS Children Villages in Ghana.

As argued by Adler, Rodman and Cropley (2014), "a communication strategy, is a communication plan, a document which expresses the goals and methods of an organization's outreach activities" (ibid: 2). It explains what an organization wishes to share with the public and whom the organization is trying to reach and in this case sponsors and potential funding bodies. This becomes feasible when the communication strategy is effective and produces a persuasive message between the target groups. It must be noted that orphanages are performing in a social and non-profitable market. As a consequence, their mission and orientation differ from the for-profit organizations because they are based on social good. When we talk of social good, it encompasses human rights, education, healthcare, environmental protection, development cooperation, sustainable livelihood and everything related to public interest in the area of social welfare and sustainability (Pradip, 2017). This is the reason why NGOs communication strategies to generate funds must be viewed differently from commercial marketing strategies which are motivated by profit. In this context, the case of orphans and other vulnerable groups are a social problem and therefore a key development challenge. This explains why the communication strategies required must be development-oriented in the drive to sensitise the public to generate the required funding.

The paper reviews some key communication strategies as the vehicles for sourcing for funds. They are Information Education and Communication (IEC), Behaviour Change Communication (BCC), Advocacy and Social Mobilization. While the words "information", "education", and "communication" have individual meanings, when grouped together as IEC, they are very synonymous with health communication. While we acknowledge that SOS CV Ghana deals with orphans whose predicaments range from health, feeding, education and shelter issues, this communication strategy is very apt as IEC integrates social change efforts for the benefit of the targeted population (Melkote \& Steeves, 2015; Servaes, 2008). Information Education and Communication (IEC) as a communication strategy is concerned with working with individuals, communities and societies to develop communication 
strategies to promote positive behaviours which are appropriate to their settings (Paola \& Cabiddu, 2016).

Behaviour Change Communication (BCC) is required to sensitise people to not only change their attitude and behavior towards the plight of orphans and the vulnerable but to see the need to contribute to their welfare. This communication strategy uses persuasion, demonstration, scaffolding and other support strategies to engender modification in behaviour of communication targets. BCC recognises that behaviour is not only a matter of having information and making a personal choice. Behaviour change also requires a supportive environment. Community and society provide the supportive environment necessary for behaviour change and this is essential if the SOS CV Ghana is to play an active role in changing the lives of the orphans and the vulnerable (Sinha, 2013).

Advocacy efforts are meant to change public perceptions and influence policy decisions and funding priorities. This communication strategy is used to educate about an issue and proffer a specific solution. All advocacies involve making a case in favour of a particular issue. Advocacy communication involves skill and persuasion to canvass support for a cause. For social mobilization, it utilises a highly participatory communication strategy which is deployed to facilitate change through a range of players engaged in interrelated and complementary efforts. Social mobilization involves engaging and motivating a wide range of partners and allies at national and local levels to raise awareness of and demand for a particular development objective through dialogue (Servaes, 2008; Melkote \& Steeves, 2015).

With funding sources on the decline, there is intense competition in the fundraising market. It means that orphanages have to settle for a better communication strategy than their competitors in order to get public attention (Nelton, 2015). It means the SOS CV Ghana must analyse the funding environment, set goals, share information, design compelling communication strategies and disseminate them persuasively. They have acknowledged the essential role that communication and media play in improving advocacy levels to a much heterogeneous audience worldwide. As McCombs et al. (2014) explain, the media educate and inform the public and also perform the role of agenda-setting which make mass media audiences to consider as important any issue which the media concentrate on. Imperatively, the communication strategies have one thing in common, that is, to assist the orphanages to attract funding by selling the stories of orphans and their plight to the various segments in the society. The media owe it to the people of Ghana to be the 'voice for the voiceless' and present the woes of the vulnerable children to the public. 


\section{Communication Challenges}

It must be noted that due to limited knowledge on SOS CV Ghana, the media sometimes publish or broadcast wrong information in relation to the works of the organisation. Lack of interest in some social events and community outreaches has hindered fundraising efforts (Baffour, 2012). As Baffour (ibid) argues, some media houses are quick to produce SOS related stories at a charge and this is crippling the finance of SOS CV Ghana, considering the fact that it operates on donor funding and support. In this regard, payment for most of its charitable events and support systems without the required return on such events to raise funds tend to worsen its financial position and put the lives of the orphans and the vulnerable at great risk. To minimise the risk, SOS CV Ghana then relies on effective communication strategies with minimal cost to project its values and works and to solicit for funding to reach out to more children in need.

In attempt to reach out to the media to provide coverage for events, the organisation sends letters of invitation with information on the event or project. This is to enable them have some details on each event. The organisation also provides press releases to some selected media houses with the view to deepen their communication which incorporates IEC, BCC, Advocacy and Social Mobilization. At the heart of highlighting its challenges, SOS CV Ghana also benefits from such media publications and broadcasts to generate appeals and to get solutions to pressing vulnerability issues that affect orphans and vulnerable children. Obregon and Tufte (2017) recommend that development communicators/journalists should take up the challenge of SOS CV Ghana by making their fund raising activities and other community outreach initiatives a priority. This responsibility means that a development reporter must critically examine, evaluate and report the relevance of development projects with such social significance as SOS CV Ghana programmes as fundraisers since its benefit to the community is unquantifiable (Melkote \& Steeves, 2015).

In this case, rationales behind fundraisers must be properly and effectively communicated. This is why the strategies are crucial in the implementation of change initiatives among the stakeholders. An understanding of the stakeholders must revolve around the purpose for which the SOS CV Ghana engages in fundraising. The sensitization must therefore incorporate the four development communication strategies, that is, IEC, BCC, Advocacy and Social Mobilization. The IEC must inform, educate and communicate clearly the essence of embarking on fundraisers to support orphans and the vulnerable at the Children's Homes. Located in this strategy is the change element as to how to convince stakeholders to change their behaviour using communication as an anchor to contribute towards 
the funding of the Homes. Advocacy and Social Mobilization through various media strategies are intended to help grab attention to the cause of the SOS CV Ghana by the deployment of press releases, radio and television documentaries, videos and short jingles on social media platforms. Other advocacy and mobilization tools are the use of vigils, and street carnivals to publicise the problems in order to generate funds for the running of the Homes (World Health Organisation, 2006).

Invariably, the objectives behind the initiatives are essential for the success of the communication strategies which ought to be organizationally driven rather than communications driven (Judith \& Graeff, 2008). The communication activities discussed earlier in the paper must not be seen as an end in itself but as part of a series of processes by the SOS CV Ghana to resource and adequately cater for the orphans. Strategic targeting and consistency are essential to the organization's messages. A comprehensive case covering all the key messages and explaining the different elements of the case for different audiences could generate the expected impact (ibid). Of note is that certain aspects of communication to seek funds for the organization are likely to arouse interest than others and bring the desired dividends. There are advocates who argue that the strategy of storytelling - use of interesting narratives, human interest stories and arresting imagery could move people to empathise and contribute generously to the cause of orphans. Other tools could be a detailed annual reports, periodic newsletters, and community durbars with the key stakeholders as the target (Judith \& Graeff, 2008).

SOS CV Ghana, on the basis of dwindling financial resources must be seen to strategically focus on outcomes and results. Strategic communications become a "must do" and no longer a "nice to do." With fewer contracting opportunities, a shift towards the lowest cost, technically acceptable procurements, and pressure to insource services are decisions which should be taken (Grable \& Goetz, 2017).

\section{Theorizing Communication Strategies}

Media Dependency and Advocacy theories are the main theories used to contextualize the central arguments in this paper (DeFleur, 2010; Ball-Rokeach \& DeFluer, 1989; Wallack \& Dorfman, 1996). Providing a definitional position on Media Dependency, DeFleur views it as a reflection of

the relationship among the mass media, their audiences, and the society as a whole and as one characterised by mutual dependency. That is, the media could not exist without the other two components. Audiences are also in a situation of dependency insofar as the media supply their members with amusements and gratifications as well as with useful 
information that would be difficult to obtain from other sources

(DeFleur, 2010: 343).

The focus of the theory is the relationship between media and audiences. In industrialized and information-based societies, individuals tend to develop a dependency on the media to satisfy a variety of their needs. Media Dependency therefore lays bare the relevance of this theory in assisting stakeholders and audiences to use media to achieve desirable benefits. In the quest to seek funding avenues to sustain itself, this paper's reliance on this theory is to help contextualise the goals of SOS CV Ghana. With increasing funding constraints by major donor agencies such as UNICEF, Department of Social Welfare (DSW) among others, SOS CV Ghana needs to widen its funding opportunities. Since stakeholders and audiences depend on media information to meet needs and reach goals, the utilization of this theory to reach out and persuade a broader base to source for funding must be seen as a significant strategy. The use of media dependency is meant to induce behavior change by virtue of targeted messages to those who are likely to be persuaded to see the need to assist with such a social endeavour (Paola \& Cabiddu, 2016).

Beside, social institutions and media systems interact with audiences to create needs, interests, and motivations in the person. Media and communication are essential levers which are relevant for mobilization, education and information dissemination to influence and inspire audiences to support a particular cause of action. Communication strategies which are deployed to persuade sponsors and others to engage in philanthropy are dependent on a key strategic vessel - media (Trenholm \& Jensen, 2013). To this end, we must acknowledge that the degree of dependence is influenced by the number and centrality of information functions and social stability.

Media advocacy theory on the other hand assumes that the mass media largely shape public debate and, consequently, political and social interventions. In context, Wallack and Dorfman (1996) defines media advocacy "as the strategic use of mass media to advance public policy initiatives" (1996: 293). From their perspective, media advocacy is rooted in community advocacy and has as its goal the promotion of public policies. Crucially, it can be differentiated from traditional mass media strategies in a number of ways. A key factor in its arsenal is that it has the ability to shift focus from the personal to the social, from the individual to the political, from the behaviour or practice to the policy or environment. As an added impetus, while traditional media approaches try to fill the knowledge gap, media advocacy addresses the power gap. 
In addressing the power gap, media savviness is necessary to get widespread coverage of certain issues and to shape how stories are presented. Thus, media advocacy adopts strategic use of mass media and community advocacy to change the social environment or advance a public policy initiative. Media advocacy adopts a participatory approach that emphasises the need of communities to gain control and power to transform their environment. It assigns the media a pivotal role in raising issues that need to be discussed and for putting pressure on decisionmakers. However, advocacy is not solely concerned with media actions (Shulman \& Sweitzer, 2018; Servaes, 2008).

According to media advocacy theory, the reliance on the media to persuade key segments in the population to support orphanages is to make information available to them and to engender a mental re-orientation towards this project. Influencing and persuading the audience to support SOS CV Ghana has a greater chance of success when the media messages target social benefits in supporting orphanages. For example, media advocacy helps to inform and educate the public and particularly the target audience about why they should contribute towards the care of SOS CV Ghana. Therefore dependence on the media and its advocacy power could help frame funding difficulties facing such organizations as everyone's problem, and the children in the SOS CV Ghana as everyone's children.

The application of Media Dependency theory in the context of seeking funding for SOS CV Ghana also has the ability to recreate and deepen the nexus of satisfying the needs of the orphanages by relying on the resources of another party. These media-audience relationships are circumscribed in the power of the media to satisfy needs through information sharing. The dividend for the audience in the case of the SOS CV Ghana is the benevolence and the joy of helping the vulnerable to become self-sustaining in the future. Drawing on the arguments of DeFleur (2010), BallRokeach and DeFleur (1989), SOS CV Ghana stands to gain in fund mobilization on the basis of greater dependency of most organizations on the media in venting their problems to the larger public in return for support. We must also recognise the agenda-setting role of the media in advocacy. By relying on the media, it not only frame funding issues in its advocacy but ensure that the media impact the audience, that is, by directing the targeted donors as to not only "how to think but also what to think about" (McComs \& Shaw, 1972: 176). The cognitive effect of audience dependency on the media is the desired attitudinal and behavioural change resulting also from agenda-setting. Again, we can speak of the compassion resulting from affective effects generated by the media due to its consumption. The media tend to generate feelings of anxiety among the audience and in this case, the 
fear of orphans being exposed to all kinds of social dehumanizing conditions due to lack of funds could impact on the sympathies of stakeholders.

The theories potency can also be seen in their capacity to transmit information that can result in people changing their attitude and behavior so as to contribute toward the funding of orphans in order to enhance their quality of life. By implication, media advocacy and dependency theories shape public debate about funding orphanages by setting the agenda for it. For example, advocacy theory which adopts a social approach identifies social conditions which militate against quality provision of education, health, housing facilities for these homes. Advocacy, mobilization and behavioural change communication strategies are reliant on these theoretical foundations to turn around precarious situations. The deployment of such strategies in seeking funding to support SOS CV Ghana are not only appropriate but fit into the greater agenda of making orphanages move away from total dependence on governments. Funding constraints necessitated by dwindling state funding and those of international bodies such as UNICEF, reinforces the tissue that local and other international sources are explored. It becomes easier to turn to other untapped areas for funding SOS CV Ghana by designing and applying media and communication strategies which hitherto have a solid theoretical foundation in order to succeed. Media dependency and advocacy theories which are interwoven with agenda-setting frames must be viewed as being key levers in solving the key needs of SOS CV Ghana.

\section{METHODOLOGY}

The mixed method deployed for the study allows for results to be presented using tables and graphs for description while interviews produced patterns and subsequently resulted in thematic analysis which lend itself to interpretation. Of interest are the demographic characteristics of the respondents sampled in the SOS CV Ghana.

The qualitative dimension of the study, interviewed ten sampled staff of SOS CV Ghana. The outcome of the interviews were placed under two sub-themes. They are communication strategies for effective fundraising and challenges in raising funds from local sources. 


\section{RESULTS AND DISCUSSION}

\section{Demographic Characteristics of Respondents}

The most significant demographic information obtained from respondents are gender, educational background, and designation or position in the organization. For gender, there were 14 males as against 16 females.

Table 1: Gender distribution of respondents

\begin{tabular}{|l|l|l|}
\hline Gender & Frequency & Percentage \\
\hline Male & 14 & 44 \\
\hline Female & 16 & 46 \\
\hline Total & $\mathbf{3 0}$ & $\mathbf{1 0 0}$ \\
\hline
\end{tabular}

Source: Field Data, 2019

The educational qualifications of the respondents are also important to the study. This is to determine if those entrusted with the care of the orphanages have the requisite qualifications. Beside, their ability to source for funding beyond the traditional sources is dependent on their educational and other social backgrounds in the area of dealing with orphanages. Worthy of note is that all the respondents have university education while 3 respondents (10\%) have Doctor of Philosophy in Child Psychology, Finance and Educational Management.

Table 2: Educational qualification

\begin{tabular}{|l|l|l|}
\hline Qualification & Frequency & Percentage \\
\hline Doctorate & 3 & 10 \\
\hline Professional & 5 & 16.7 \\
\hline $2^{\text {nd }}$ Degree & 9 & 30 \\
\hline $1^{\text {st }}$ Degree & 13 & 43.3 \\
\hline Total & $\mathbf{3 0}$ & $\mathbf{1 0 0}$ \\
\hline
\end{tabular}

Source: Field Data, 2019

The quality of the staff of SOS CV Ghana is further demonstrated in Table 3 with $5(16.7 \%)$ staff possessing professional qualifications as Chartered Accounts and Chartered Marketers. Both the $2^{\text {nd }}$ Degree and $1^{\text {st }}$ Degree graduates constitute $30 \%$ and $43.3 \%$ of the total sampled staff used for the study. 
Table 3: Position of respondents

\begin{tabular}{|l|l|l|}
\hline Position & Frequency & Percentage \\
\hline Senior Management Staff & 5 & 16.7 \\
\hline Senior Staff & 7 & 23.3 \\
\hline Junior Staff & 18 & 60 \\
\hline Total & $\mathbf{3 0}$ & $\mathbf{1 0 0}$ \\
\hline
\end{tabular}

Source: Field Data, 2019

As usual of most organizations, the senior management and senior staff constitute $40 \%$ of the top echelon in the SOS CV Ghana. Clearly, the majority of staff is at the base of the organizational structure and that their influence on helping the organization raise domestic funding is paramount. It was also realised that the organization has a different grading system for their staff. Thus a degree holder can still be a junior staff while managerial positions are offered based on higher qualifications, experiences and length of service.

As earlier stated in this paper, the main objective of the paper is to examine the relevance of communications strategies in improving domestic funding of orphanages in Ghana. This has been empirically tested and the results are presented below.

\section{Relevance of Communication Strategies for Domestic Funding}

At least $50 \%$ of the respondents claimed that communication strategies greatly impact the organization's operations (Table 4). Respondents were also given the opportunity to rate the existing communication strategies used to seek funding.

Table 4: Impact of communication strategies on funding

\begin{tabular}{|l|l|l|}
\hline Category & Frequency & Percentage \\
\hline To a greater extent & 15 & 50 \\
\hline To some extent & 14 & 46 \\
\hline Not at all & 1 & 3 \\
\hline Total & $\mathbf{3 0}$ & $\mathbf{1 0 0}$ \\
\hline
\end{tabular}

Source: Field Data, 2019

In grading their communication strategies with stakeholders to source for funding, majority of the respondents that is, over $60 \%$ rated communication strategies used as being below average (Table 5). 
Table 5: Grading SOS CV Ghana communication strategies

\begin{tabular}{|l|l|l|}
\hline Category & Frequency & Percentage \\
\hline $1 \%-20 \%$ & 3 & 10 \\
\hline $21 \%-40 \%$ & 13 & 43 \\
\hline $41 \%-60 \%$ & 12 & 40 \\
\hline Above 60\% & 2 & 6 \\
\hline Total & 30 & $\mathbf{1 0 0}$ \\
\hline
\end{tabular}

Source: Field Data, 2019

Paradoxically, 33\% of the respondents strongly agreed (Table 6). This means that to the majority of the respondents, the organization has good communication strategies in seeking domestic funding.

Table 6: Perspectives of communication strategies adopted

\begin{tabular}{|l|l|l|}
\hline Category & Frequency & Percentage \\
\hline Strongly agree & 10 & 33 \\
\hline Agree & 12 & 40 \\
\hline Indifferent & 3 & 10 \\
\hline Disagree & 5 & 16 \\
\hline Total & $\mathbf{3 0}$ & $\mathbf{1 0 0}$ \\
\hline
\end{tabular}

Source: Field Data, 2019

In the area of deliberate policy to train staff to use the various communication strategies effectively in the midst of funding constraints being experienced, the respondents' perspectives are graphically captured below in Figure 1. 


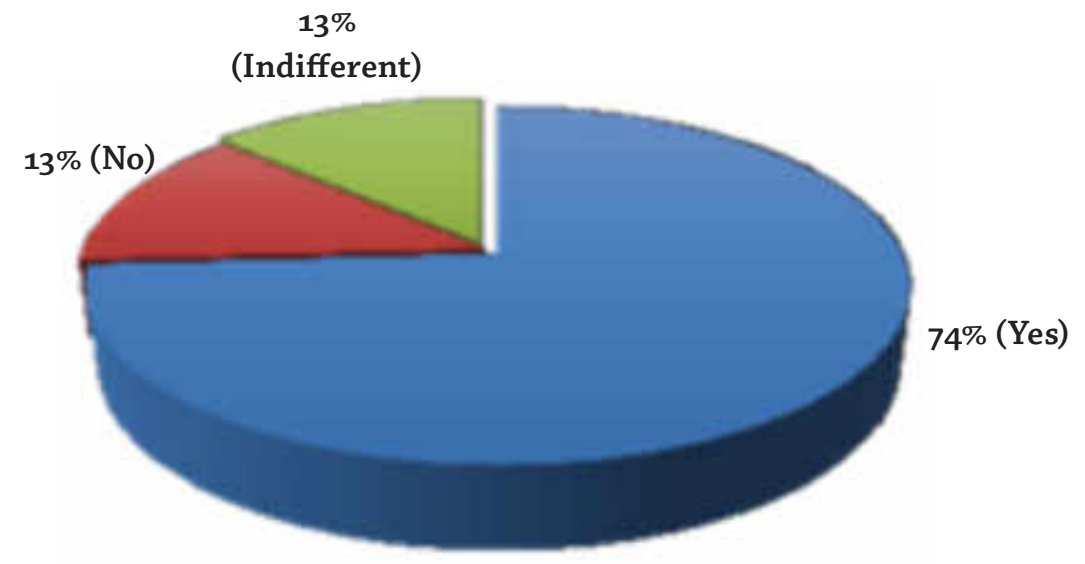

Figure 1: Staff training on effective communication strategies

Source: Field Data, 2019

As shown in Figure 1, 74\% of the respondents selected YES as a confirmation that management organises training for staff in effective communication using the required strategies. In the No category of $13 \%$ claimed there was no such training with another $13 \%$ remaining indifferent. However, on the adequacy of communication resources available for fundraising to advance objectives, these are the responses as seen in Figure 2:

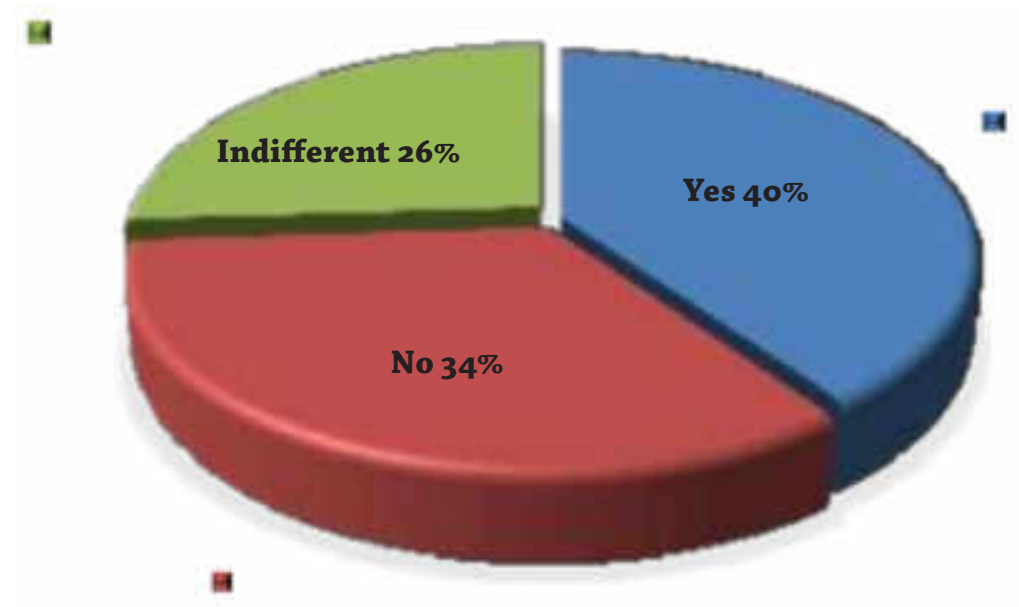

Figure 2: Adequacy of communication resources

Source: Field Data, 2019

As can be seen from Figure 2, in responding to whether the organization has adequate communication resources to seek for sponsorship/fundraising, 
majority of the respondents indicated that indeed the organization has adequate communication resources representing 40\%, but 33\% of the staff disagreed meaning that not all the staff agree that the organization has adequate communication resources.

\section{Communication Strategies for Effective Fundraising}

Interviews with top management of SOS CV Ghana revealed that fundraising strategies using communication tactics are critical to the survival of the orphanages because the organization itself does not engage in any profit venture. A senior manager of the organization states:

Much of our funding comes from third party funding organizations. So what is done is that we develop a comprehensive long-term programme with communication and media strategies very central to seeking funds. These programmes are broken into smaller bits so that we can seek funding for each part, from the same or sometimes different sources. Because of our staff strength, we rely a lot on the media. So when l said we take communication strategies seriously in seeking funding, you understand (Manager-2).

This shows that SOS Children's Villages Ghana strategically breakdown long term projects and applies different communication strategies to raise funds for different parts of the programme. This is a project-based approach and the communication strategies deployed must depict same. For another manager the organization uses a diversified approach to fundraising such that they use different communication tactics for foreign and local donors. Although this study is about local fundraising, it was evident from the interviews that the managers were more interested in foreign donations because they claimed foreign donors offer more support than local ones. She explained:

We use a diversified fundraising programme. Over time we have realised that the closer the donor, the smaller the amount. A person walking on the street in your town may provide only small change that he currently has in his pocket. But more 'distant' persons and organizations provide more funding depending on the communication approach we use (Manager-1).

The response of the manager implies that SOS CV Ghana uses different communication strategies to pursue different categories of stakeholders, but their main focus turns to be on distant donors. This implies that very little support is received from the immediate communities in which the SOS CV Ghana operates. This Manager added that due to the availability of the internet, their communication 
focuses on online portals and the wire services. Due to the reach of wire services, their communication strategies target both organizations and eminent persons in the country and those in the diplomatic missions operating in Ghana. As Manager 3 revealed:

We do organise outreach programmes in order to sensitise our target audience and stakeholders about the plight of the orphans and why they need to be assisted to realise their full potential in education. The types of information communication and education materials we develop for this exercise are meant to draw some level of sympathy. The essence is also to put before the public major strides we've made as an organization.

As Manager 3 explains, they do not just appeal for funds but also showcase the strides being made by the orphans in the Homes. For example, she revealed that they sometimes incorporate personal experiences and exploits of the children in the Homes and in particular those who have made it to the very top of the educational ladder in such advocacy programmes.

Another senior management staff (Manager 5 ) revealed that the organization was able to mobilise some resources locally and it is also able to benefit from its extensive network. This she attributed to effective use of media advocacy and social mobilization strategies to explain and persuade the stakeholders and the public in general about how the resources are used by the organization.

Local resource mobilization provides potential NGOs to raise funds from local businesses and individuals. To do this we have to put in place strong governance and accountability mechanisms, clear strategies and local credibility. Everyone who knows SOS has respect for what we do because we rank accountability and transparency very high (Manager 5).

It emerged that the organization takes advantage of the network of NGOs to fraternise and learn about new and effective fundraising mechanisms. In order to this,

Local networking provides opportunities for mutual learning, identifying appropriate target audience and the persuasion of same to change their attitude and behavior in order to support our initiatives. We also harmonise our approaches to development using the right communication strategies, and by pursuing effective local advocacy using community communication outlets such as community radio and poster. The strategies used in reducing health risks and promoting behavioural 
change in other spheres of development communication is also applied to attract financial support for the children as well (Manager 4).

The use of community communication outlets, he noted are basically geared to bring about attitude and behavioural change. With the communities at the centre of development, the Managers also make use of them as focal points. As Manager 4 added "the community radio is more effective for social mobilization because it is in the locality and a useful tool for engineering consent for programmes and projects".

\section{Challenges in Raising Funds from Local Sources}

It was found out that the socio-economic environment influences how far SOS CV Ghana is able to take their fundraising efforts. Since most organizations involved in charity work are Non-Governmental Organizations (NGOs), some of these institutions are located within the civil society space. To this end, their responses to funding of SOS CV Ghana are dependent on both the economic and political climate. This was how a Senior Staffer 3 captured it:

That is, national level space for civil society is highly dependent on the state of democratic governance and the openness of government towards civil society operations is also essential. As such when the country is experiencing economic hardship, it affects the ability of economic agents to donate to us (Senior Staff - 3).

Another interviewee (Senior Staffer - 1), believed that it was a matter of capacity. According to this staffer, existing capacity to donate is low for many individuals and organizations. He explained that, the capacity for SOS CV Ghana to identify and approach all potential donors is also low for the organization.

First of all, some people have the interest and the heart to donate but they do not have the resources. Secondly, we also cannot identify and approach every organization and individuals because we have inherent capacity limitations. Sometimes, some organizations have to be lobbied for a long time before they donate. We are still developing the capacity for such persistent and long-term communication.

It was also realised that some people still expect NGOs to raise funds abroad and not internally. "Oh yes! That is true", Manager 5 revealed. According to her, "many people still think that all NGOs should raise funds from foreign sources. As a result even organizations which have the means to support would rather do a direct project than donate to an orphanage or other NGOs". 
It also emerged that there is an eminent problem of sustainability. Both internationally and locally, the number of NGOs has increased and the funds available for charity projects continue to shrink. Therefore generating funds from local sources has become even more herculean. Senior Staff 2 asserts that:

Financial sustainability is one of the key challenges for NGOs in the next decade. Only those institutions that have sound financial structures and stable income flows will be able to fulfil their multiple missions and respond to the current challenges in an increasingly complex and global environment. SOS CV Ghana is an international organization so we are better off compared to some other organizations, but we need to be able to raise funds domestically in order to remain relevant.

This position of Senior Staff 2 has been corroborated further by Manager 1, who explained that the challenges in raising funds from local/domestic sources is getting more difficult by the day due to certain negative perceptions. For example, she noted that the misappropriation of funds, corruption and misuse of equipment donated by some stakeholders is affecting resource mobilization. She further stated that some of the staff of these organizations not only misuse equipment meant for use by the children but also divert funds.

There are problems of accountability both vertically and horizontally. For example, one cannot donate 10 tons of food such as rice, maize, oil, cowpeas, canned fruits, meat, fish, and flour among others and only to hear within a few weeks that the children in SOS CV Ghana are on the verge of starvation (Manager - 1).

What this means is that the challenges facing SOS CV Ghana is not only the application of communication strategies to woo stakeholders. Rather, there are obvious accountability and transparency issues which add up to the constraints.

\section{CONCLUSION AND RECOMMENDATIONS}

The overarching position of this paper is that communication strategies are essential in assisting SOS CV Ghana to generate the required funds to run the orphanages. Going by the mixed method, the quantitative and qualitative results provide a fascinating blend of the qualities inherent in the staffing and the strategies used to seek funding for the SOS CV Ghana. The paper also revealed that the synergy produced when organizations come together to network and share ideas are crucial to ensure the survival of the Homes. While a true consensus about all issues among all stakeholders is unrealistic, the deployment of communication 
strategies with the view to change attitude and behaviour among the population to embrace the importance of SOS CV Ghana must be seen as an important vehicle for solving funding challenges.

From the standpoint of the methods and literature, it is evident that a more nuanced approach is required to sustain the funding of orphanages. The challenges being faced by the organization are also due to inadequate communication resources to motivate the local population to contribute their quota. While the challenges to raise funds locally has been acknowledged, sight must not be lost on the external factors as well as the socio-economic and political environment which ought to be congenial in order to motivate stakeholders and the people in general to contribute. The inability of the local sources to play a key part in resource mobilization has been traced to perceived corruption and misappropriation by some of those in charge of the Homes. Moreover, as was found out in this study any successful organization has one major attribute that sets it apart from unsuccessful organizations: dynamic and effective leadership or management who appreciates and acknowledges communication.

The nexus of communication strategies and funding gaps require a more radical approach in the face of dwindling local and international sponsorship for the Homes. Deeper awareness creation and reorientation of the stakeholders to appreciate the funding conundrum would need a key vehicle like the media in this millennium. Therefore the arguments and critiques which struck at the heart of media advocacy and dependency theories have been useful in bringing to the fore the steps needed to solve the problem. Deploying communication strategies within the domain of development communication is very relevant because the whole essence of the SOS CV Ghana is to cater for the children, bring them up to the level of others who are privileged to be with their biological parents. Their basic needs are education, health, shelter and food. And in the era of information society, well designed and planned communication strategies are the elixir among other strategies to realise this dream. To this end, a national policy framework by government to ensure that the Ghanaian media make their platforms available gratis for fundraising and advocacy work is essential if the funding conundrum is to be resolved. It is also the position of this paper that a national fund is established whereby a percentage of taxes collected from the citizens are lodged and expended on orphanages in order to improve the quality of care in these homes.

\section{REFERENCES}

Adler, R.B. Rodman, G.R. and Cropley, C. (2014). Understanding human communication (11 ${ }^{\text {th }}$ ed.). New York: Oxford University Press, pp. 2-4. 
Baffour, K.P. (2012). The liberative power of education: Adult basic education as empowerment tool for rural women. Tribes and Tribals, 10 (2), pp. 91-97.

Berens, A.E. and Nelson, C.A. (2015). The science of early adversity: is there a role for large institutions in the care of vulnerable children? Lancet, 386 (9991), pp. 388-398.

Creswell, J.W. (2003). Research design: Qualitative, quantitative and mixed methods approaches. Thousand Oaks, CA: Sage, pp. 22-26.

DeFleur, M.L. (2010). Mass communication theories: Explaining origins, processes, and effects. New York: Allyn and Bacon, p. 343.

DeFleur, M.L. and Ball-Rokeach, S. (1989). Theories of mass communication (6th ed.). New York: Longman, pp. 29-42.

Department of Social Welfare Ghana (2015). Consensus of street children in Greater Accra Region. Accra: Ghana, pp. 46-50.

Grable, J.E. and Goetz, J.W. (2017). Communication essentials for financial planners:Strategies and techniques. NJ: Wiley, pp. 173-187.

Judith, A., and Graeff, J.A. (2008.) Writing development communication strategy: A guideline for programme managers and communication officers. Dhaka: UNICEF, pp. 36-37.

McCombs, M., Shaw, L. and Weaver, D.H. (2014). New directions in agenda-setting theory and research. Mass Communication \& Society, 17(6), pp. 781-802.

McCombs, M. Shaw, D. (1972). The agenda-setting function of mass media. Public Opinion Quarterly, 36 (2) pp.176-187

Melkote, S.R., and Steeves, H.L. (2015). Communication for development: Theory and practice for empowerment and social Justice (3rd Edition). London: Sage, pp. 337339.

Mensah, E.T. (2010). National plan of action for orphans and vulnerable children. Accra: Assembly Press, p.3.Moffat, S. (2015). Contextualizing scientific research methodologies. IOSR Journal of Research and Method in Education, 5(6), pp. 52-57.

Nelton, W.R. (2014). Conflict management style and leadership effectiveness: The moderating effects of gender. Sex Roles, 29, pp. 405-418.

Obregon, R. and Tufte, T. (2017). Communication, social movements, and collective action: Toward a new research agenda in communication for development and social change. Journal of Communication, 67(5), pp. 635-645. 
O’Donoghe, K.L.(2014). Barriers to parental involvement in education: An explanatory mode: Developing diverse programs to include unique demographics. Master's thesis, (1), p. 6.

Paola, B.F.A., and Cabiddu, F. (2016). Social media communication strategies. Journal of Services Marketing, 3 (5), pp. 490-503.

Pradip, N.T. (2017). Contentious actions and communication for social change: The public hearing as process. Journal of Communication, 67(5), pp. 719-732.

Paola, B.F.A., and Cabiddu, F. (2016). Social media communication strategies. Journal of Services Marketing, 30(5), pp. 490-503.

Right to Education Factsheet Ghana (2012). Available at http://www.right-to-

education.org/sites/files/resources-attachments/rte-country-factsheetGhana-2012. Accessed 29th June, 2019.

Servaes, J. (ed.) (2008). Communication for development and social change, 2nd Edition. London: Sage, pp. 2-3.

Sinha, D. (2013). Development communication: Contexts for the 21st century. New Delhi: Orient Blackswan Private Limited, p. 2.

Shulman, H. and Sweitzer, M.D. (2018). Advancing framing theory: Designing an equivalency frame to improve political information processing. Human Communication Research, 44(4), pp. 155-175.

Wallack, L. and Dorfman, L. (1996). Media advocacy: A strategy for advancing policy a and promoting health. Health Education Quarterly, 23(3), pp. 293-317.

World Health Organisation (2006). Advocacy, communication and social mobilisation to fight tuberculosis: A 10-year framework for action. Geneva: WHO Press, pp.15-16. 